\title{
Analysis of Current Situation and Development Tendency of Russian Diplomatic Policy in New Environment
}

\author{
Zixin Yan ${ }^{1}$ \\ ${ }^{1}$ Sichuan Agricultural University, Ya’an, 625000, China
}

Keywords: Russia; Diplomatic policy; Putin

\begin{abstract}
As a Eurasian power, Russian diplomatic policy is of great concern in international politics. In the new environment of the world, it is of great significance to analyze Russia's diplomatic status and explore Russia's diplomatic tendencies. In recent years, Russia has built a diplomatic tone of national identity and a diplomatic strategy to enhance its soft power. Under the new environment, Russia will strengthen the cooperation with China, deepen relations with the United States, promote diplomacy with the CIS countries, and attach great importance to the diplomacy with the Asia Pacific countries to realize the all-round development of Russian diplomacy.
\end{abstract}

\section{Introduction}

After the breakup of the Soviet Union, Russia was aware of the importance of active public diplomacy in the face of the impact of Western cultural values and the threat of Westernization. From the period of Yeltsin to the implementation of public diplomacy, to a climax to the period of Putin, and in the past few years, President Medvedev has used the Putin route in many ways and has also taken various measures to carry out public diplomacy. Russia has a long history and a vibrant culture. The historical writers Pushkin, Lev Troels Tai and musician Tchaikovsky all show that Russia has rich cultural resources, and its literature and music play an important role in the world. A strong cultural atmosphere has provided a powerful impetus for Russian public diplomacy. Russian culture can not only tolerate other cultures, but also, to a certain extent, is easy to accept other cultures and absorb the essence of other cultures. Cultural factors are very heavy in Russian public diplomacy, which makes Russian public diplomacy pay more attention to long-term knowledge conservation and pay more attention to the identity attitude of the foreign public to the country. Russian public diplomacy is a communication between culture and culture in a peaceful atmosphere. Russia has always attached great importance to the use of the power of leaders to carry out public diplomacy, for public diplomacy activities, the purpose is to attract the attention of foreign public. The image of President Putin's popularity is largely the result of the effective use of public diplomacy by the Russian government. Since the collapse of the Soviet Union, Russia's first great power in the minds of the world's people and governments has been greatly improved. Putin has shown the image of the new leader of Russia to the world. He is good at using the media to actively publicize and promote its diplomatic strategy, which is conducive to promoting and affecting the image of the country.

\section{Current Situation of Russian Diplomatic Policy in New Environment}

\subsection{Keynote of Diplomatic Policy: National Identity}

National identity is a country's clear understanding of self-identity, which reflects the difference between a country and another country. From the domestic dimension, national identity is an important source of national belonging and political legitimacy. From the external dimension, national identity is the role of a country relative to the international community, which embodies the international position of self, reflects the international view of a country, and is an important ideological basis for a country to understand the international order. Russia's national identity is one of the problems that have a major impact on the current international situation and world structure, 
but it is also one of the most uncertain factors. Russia's national interest is the basis for formulating the strategic task of internal and external policies. As far as content is concerned, internal and external policies are a concentrated reflection of the vital interests of individuals, society and the state. The requirements of national interests and their time and space may change with the changing conditions at home and abroad. Therefore, the Russian national identity will also develop and change, but in any case, the ruling class's deepening of the Russian national identity is a coherent whole process. Russia does not rely on finance or economy to maintain domestic security and political stability. In fact, Russia's national governance relies on its own means, which are summed up in six pillars: geopolitical position, political control, national mentality, natural resources, use of soldiers and powerful departments. Geopolitical location means that Russia borders on most areas that it wants to put in power, and there is no geographical barrier to separate it from its own goals. Russia can exert all kinds of influence and deterrence on the ground at low cost. Political control refers to the centralization of power structure. The strong department refers to Russia's powerful intelligence agencies and has always been Russia's strongest pillar.

\subsection{Strategy of Diplomatic Policy: Soft Power}

Russia's soft power policy is achieved through the national popularization of the Russian unique ideology, relying on the economic and political appeal of the underdeveloped countries and the exaggeration of the media to publicize external threats. It can be said that rich cultural resources help Russia maintain a good cultural image from the cultural, historical, political and economic factors contained in the image of the country, but Russia lacks the values that can affect the world, and its inherent political image with a threat is more Russian. With the influence factors of the west, Russia has long been in the middle level of the list of countries to judge the soft power of the country. The radiation scope of the national soft power is limited to the region, and its soft power strategy is more like a part of the internal development strategy than the external development strategy. The process of globalization is further deepening, and the pattern of international relations continues to develop into multi polarization. Regional organizations such as emerging market countries and Shanghai cooperation organizations and BRIC countries have changed the structure of international economic, political and security discourse with the rapid rise of strength, and the importance of cooperation among countries to resist risks has risen. It is against this background that Russia's national image has changed, prompting Moscow to decide on diplomatic transformation and soft power policy adjustment. It is under the background that the former Russian soft power has certain basic conditions and the reality of the country is not recognized by the outside world. The Russian diplomatic Department began to reassess the international situation and self-identity and thought that the idea of building an oasis of stability and safety for individuals under the conditions of rapid global change and increasing interdependence of each country Be unsuccessful. Russia will continue to play its balance role in solving international affairs and developing world civilization in a century.

\section{Development Tendency of Russian Diplomatic Policy in New Environment}

\subsection{Strengthen the Cooperation with China}

Russia regards China as the most important and most promising country in economic cooperation. Russia clearly supports China in the South China Sea dispute. Russia and China have affirmed the progress of bilateral relations and have made new strategic consultations aimed at deepening bilateral pragmatic cooperation. At the same time, China and Russia have continued to deepen their economic cooperation. In the field of economic and trade cooperation, Sino Russian economic and trade cooperation has developed well in recent years, and the volume of trade has increased geometrically. Moreover, the scale of investment cooperation between the two countries has gradually increased, especially China's investment in Russia has increased rapidly, and bilateral investment has exceeded three billion US dollars. In the field of energy cooperation, when the Russian leader visited China, the two sides announced the full opening of the Sino Russian crude oil pipeline. And now it is in normal operation. In recent years, Russia has sent a lot of crude oil to China. At the same time, Sino Russian 
cooperation in natural gas has also made great progress. China and Russia have reached a consensus on the price of natural gas and achieved the goal of supplying Russia with China as soon as possible. China and Russia are also building a refinery with a design capacity of ten million tons in Tianjin and cooperation with downstream oil products processing. In the field of financial cooperation, China and Russia have agreed to deepen the settlement of RMB and ruble in bilateral trade, expand the settlement ratio of RMB and ruble in bilateral trade, and set up the ruble and RMB trading mode in China and Russia. In view of the latest developments in Sino Russian relations, the two countries' comprehensive strategic cooperative partnership continues to advance steadily. At present, the relationship between the two sides is more abundant than ever before. The two countries are highly trusted in politics, and the dialogue and cooperation mechanisms at all levels are becoming more and more perfect. With mutual support in core interests, the social foundation of Sino Russian strategic partnership has been consolidated, and the economic cooperation between the two countries has continued to jump to a new level.

\subsection{Deepen the Relationship between Russia and America}

In the current stage, the relationship between Russia and the United States has not yet been fundamentally changed. The underlying reason lies in the fact that hostility and mutual distrust between Russia and the United States are deep-rooted. In the United States, its distrust of Russia is rooted in the uneasiness of the us to Russia, which is based on the long-term confrontation of the cold war; in Russia, its attitude towards Russia after the end of the cold war is still wrath at the end of the US cold war, while still preserving the US policy aimed at weakening Russia. Quite a doubt. Russia first initiatively deepened its relations with the United States and deepened bilateral coordination on some hot issues. On the Afghan issue, Russia agreed that the United States and NATO should transport goods from Russia to Afghanistan and cooperate in combating drug trafficking in Afghanistan. In the light of the Middle East issue, we will deepen the Middle East peace process in an all-round way. Russian leaders have held talks on the nuclear issue between Palestine and Israel and Iran. On the issue of us Russia relations, Russia has dealt with the espionage case in a low profile to ensure the comprehensive progress of bilateral relations. At the same time, the two countries issued a joint statement on the partnership for innovation in the field of innovation and maintained a unified view on deepening the cooperation in the field of innovation and economic development, and Russia publicly expressed that the innovative economy should be attached to the technical support of the United States. At the same time, Russia reopened its relationship Great powers such as the United States have called for Russia to military cooperation. Russia must deepen cooperation with developed countries in order to implement the modernization strategy. At the same time, Russia carried out the first summit after the conflict, and reached consensus on dealing with new security threats and missile defense. Russia also accepted the invitation of NATO's defense system cooperation, while Russia agreed to transport related materials to and out of Afghanistan through Russia and on this basis to expand transit transport types.

\subsection{Promote Diplomacy with CIS Countries}

As a country connected to and connected to the above countries, Russia has begun to intensify its efforts to form an independent power center in the northern Eurasian continent. Russia wants to be a real power center in the world, with sufficient foundation to make itself an independent power and an independent center of the multipolar world. The first thing that Russia needs to do is to realize the integration of space in the post-Soviet Union. Russia has deepened its diplomacy with the Commonwealth of Independent States in the light of the fact that Europe and the United States are busy with their own affairs and ignore the CIS. Based on the customs union of Russia, Russia and Kazakhstan, we will promote regional integration. Through Customs Law of the customs union, the three countries build a unified customs area and build a unified economic system on this basis. At the same time, Russia has taken the initiative to promote the establishment of a cis free trade area. The CIS free trade area agreement has also been signed. This document is attached to the WTO rules and provides effective legal protection for the economic and trade cooperation between the CIS countries. Russia's move not only suppressed the centrifugal regime within the Commonwealth of Independent 
States but also deepened Russia's leading role in this region. Russia enhances cohesion through deepening military and security cooperation. First, Russia has increased its presence in other countries' military bases to the middle of this century. At the same time, Russia and Abkhazia signed an agreement on Russia to set up a military base in Abkhazia, which was used for forty-nine years; Russia and Ukraine signed an agreement, and Ukraine agreed to take the Russian Black Sea Fleet in Sevastopol on the Crimea Peninsula in southern Ukraine. The length of the port's stay is extended to 2042, and it can be reconsidered for five years. Meanwhile, Russia's military base in Armenia is extended to 2044.

\subsection{Emphasize Foreign-policy of Asia Pacific Countries}

Russia will strengthen its position in the Asia Pacific region as a strategic direction of foreign policy. Russian Federation will continue to uphold the principle of establishing good neighborly relations with Japan and developing mutually beneficial cooperation, including the purpose of ensuring stability and security in the Asia Pacific region. Russian Japanese relations are one of the most important relations among great powers in international relations since modern times. There have been many wars in the history of the two countries. Russia and Japan have failed to conclude the peace treaty today. Russia and Japan are China's two largest neighbors. The development of Russian Japanese relations will directly affect the strategic layout, peace and stability of the Far East and directly affect China's security and development environment. Russia has been paying attention to the Far East for a long time and has held several special meetings on this basis to make decisions on how Russia attaches importance to the strategy and intervenes in East Asian affairs. The Russian leadership has categorized Asia-Pacific countries into Russian partners. Russia focuses on the growing strength of emerging Asian countries. At the conference on social and economic development in the Far East, the Russian leaders showed that economic integration with the Asia Pacific countries is an effective measure for the economic revitalization of the Russian Far East. At the same time, Russia has also deepened its cooperation with the Asia Pacific countries. In a short time, Russian leaders visited India several times, and the two sides signed several cooperation agreements, including military technology, nuclear energy and space. The two countries have made great progress in the field of military cooperation: Russia not only refuses the aircraft carrier for India, and exports to India twenty-nine fighters, but also the two countries have signed a joint development of the fifth generation of aircraft agreement. And Russia deepened its cooperation with Vietnam. Russian leaders visit Vietnam and attend the second summit. The two countries signed several agreements, including military technology cooperation, nuclear power plant construction and customs affairs, and set up an investment fund of five hundred million US dollars.

\section{Conclusion}

In 2018, Putin won the presidential election and became the maker of Russian foreign policy. As a large country with vast territory, rich resources and great potential, the situation of the interaction between Russia and the international community in the future is related to the international pattern and the peace and stability of the world. It also concerns the geopolitical ecology of the Eurasian continent, especially the security and stability of China's surrounding environment. It will present the tendencies of reinforce of the cooperation with China, the furtherance of the relationship between Russia and America, the promote diplomacy with CIS Countries and the important foreign-policy of Asia Pacific countries.

\section{References}

[1] Liu Jun. Russia and the West: The Path Choice of Russian Foreign Policy in the Past 30 Years [J]. Journal of East China Normal University (Humanities and Social Sciences), 2017(2): 125-131+184.

[2] Liu Ying, Guan Haiting. The Adjustment of Soft Power Policy During the New-Periodical Russian Diplomatic Transformation [J]. Northeast Asia Forum, 2015(1): 72-85+128. 
[3] Huang Dengxue. Analysis of the Foreign Policy of Russia during Putin's New Presidency [J].2013, 15(4): 14-19+79.

[4] Xue Fuqi. "Splendid Isolation”, Involution and Ambition - Analysis of the Trends of Russia's Domestic and Foreign Policy under Uncertain Conditions [J]. Frontiers, 2017(19): 44-51. 